HorTSCIENCE 55(8):1288-1294. 2020. https://doi.org/10.21273/HORTSCI14653-20

\title{
A Survey of Rose rosette virus and Eriophyid Mites Associated with Roses in the Southeastern United States
}

Katherine M. Solo and Sara B. Collins

Department of Entomology and Plant Pathology, University of Tennessee, Knoxville, TN 37996

Madalyn K. Shires

Department of Plant Pathology and Microbiology, Texas A\&M University, College Station, TX 77845

Ron Ochoa

U.S. Department of Agriculture, Agricultural Research Service, Systematic Entomology Laboratory, Beltsville, MD 20705

Gary R. Bauchan

U.S. Department of Agriculture, Agricultural Research Service, Electron and Confocal Microscopy Unit, Beltsville, MD 20705

Liesel G. Schneider

Department of Animal Science, University of Tennessee, Knoxville, TN 37996

Alan Henn

Department of Biochemistry, Molecular Biology, Entomology, and Plant Pathology, Mississippi State University, Starkville, MS 39762

James C. Jacobi

Alabama Cooperative Extension System, Auburn University, Birmingham, AL 35223

Jean L. Williams-Woodward

Department of Plant Pathology, University of Georgia, Athens, GA 30602

M.R. Hajimorad

Department of Entomology and Plant Pathology, University of Tennessee, Knoxville, TN 37996

Frank A. Hale

Department of Entomology and Plant Pathology, University of Tennessee, Nashville, TN 37211

John B. Wilkerson

Department of Biosystems Engineering and Soil Science, University of Tennessee, Knoxville, TN 37996

Alan S. Windham

Department of Entomology and Plant Pathology, University of Tennessee, Nashville, TN 37211

Kevin L. Ong

Department of Plant Pathology and Microbiology, Texas A\&M University, College Station, TX 77845

Mathews L. Paret

Plant Pathology Department and North Florida Research and Education Center, University of Florida, Quincy, FL 32351

Xavier Martini

Entomology and Nematology Department, North Florida Research and Education Center, University of Florida, Quincy, FL 32351

David H. Byrne

Department of Horticultural Sciences, Texas A\&M University, College Station, TX 77845

\section{Mark T. Windham}

Department of Entomology and Plant Pathology, University of Tennessee, Knoxville, TN 37996

Additional index words. Eriphyes eremus, mite extraction, Phyllocoptes fructiphilus, TaqMan RT-qPCR

Abstract. The eriophyid mite, Phyllocoptes fructiphilus, vectors the causal agent, Rose rosette virus (RRV), that results in rose rosette disease. Parts of the southeastern United States have remained free of the disease, except for infected plant material introductions that were eradicated. A survey of sampling points through Alabama, Georgia, and Mississippi $(n=204)$ revealed the southeastern border of RRV. The presence of RRV in symptomatic plant tissue samples $(n=39)$ was confirmed by TaqMan-quantitative reverse transcription polymerase chain reaction (RT-qPCR). Samples were also collected at every plot for detection of eriophyid mites, specifically for $P$. 
fructiphilus. Three different species of eriophyid mites were found to be generally distributed throughout Alabama, Georgia, and Mississippi. Most of these sites $(n=60)$ contained $P$. fructiphilus, found further south than previously thought, but in low populations ( $<10$ mites/gram of tissue) south of the RRV line of incidence. Latitude was found to be significantly correlated with the probability of detecting RRV-positive plants, but plant hardiness zones were not. Plot factors such as plant size, wind barriers, and sun exposure were found to have no effect on $P$. fructiphilus or the presence of RRV. The reason for the absence of RRV and low populations of $P$. fructiphilus in this southeast region of the United States are unclear.

Rose rosette disease (RRD) has become established across much of the United States. The causal agent is Rose rosette virus (RRV) (genus Emaravirus) (Di Bello et al., 2015; Laney et al., 2011), with the main mode of natural transmission being the eriophyid mite, Phyllocoptes fructiphilus Keifer (Allington et al., 1968; Amrine et al., 1988; Bauchan et al., 2019; Gergerich and Kim, 1983), although the virus can be spread through grafting (Amrine et al., 1988; Gergerich and Kim, 1983) and movement of infected plant material. Eriophyid mites can use wind currents to disperse long distances to new locations (Galvao et al., 2012; Lindquist and Oldfield, 1996; Zhao and Amrine, 1997). The relationship between virus and vector and mode of virus transmission are unknown. However, more than just passive transport is suspected. Five other eriophyid mites are known to infest roses in the United States but are not known to transmit RRV: $P$. adalius, $P$. linegranulatus, $P$. chorites, Callyntrotus schlechtendali (Baker et al., 1996; Keifer, 1939a, 1939b, 1940, 1972; Otero-

Received for publication 18 Feb. 2020. Accepted for publication 29 May 2020.

Published online 6 July 2020.

We would like to thank the U.S. Department of Agriculture (USDA), National Institute of Food and Agriculture (NIFA) for a Specialty Crop Research Initiative Grant (2014-51181-22644/SCRI), "Combatting Rose Rosette Disease: Short Term and Long Term Approaches," providing funding for this project. The Florida studies were conducted with funding from the Florida Nursery Growers and Landscapers Association.

We thank Jim Amrine, Jr. for the training and discussion on rose mites and help with material and notes on rose rosette disease. To Debra Creel and Andrew Ulsamer [Systematic Entomology Laboratory (SEL)-USDA] for their help with references and technical support. To Chris Pooley [USDA, Agricultural Research Service (ARS), Electron and Confocal Microscopy Unit] and Joe Mowery (USDA-ARS, Electron and Confocal Microscopy Unit) for their help with the figures and IT expertise. To the Department of Entomology and Plant Pathology, University of Tennessee, Knoxville; the Smithsonian Natural History Museum; and the National Agricultural Library (NAL-USDA), SEL-USDA for support and assistance with specimens and references.

Mention of trade names or commercial products in this publication is solely for the purpose of providing specific information and does not imply recommendation or endorsement by the USDA; USDA is an equal opportunity provider and employer.

K.M.S. is the corresponding author. E-mail: kbaker46@vols.utk.edu.

This is an open access article distributed under the CC BY-NC-ND license (https://creativecommons. org/licenses/by-nc-nd/4.0/).
Colina et al., 2018; Styer, 1974), and Eriophyes eremus (Otero-Colina et al., 2018).

RRV is lethal to roses; and, like most other plant virus infection, there is no cure once roses are infected. Cultivated roses and many Rosa species are susceptible, including the noxious weed $R$. multiflora Thunb. (multiflora rose). Beds of ornamental roses and wild multiflora roses can serve as reservoirs of both the mite and the virus. Although control of multiflora rose is recommended, it is often difficult due to the numerous seeds produced annually, remote growing location, and regeneration of shoots from roots left in soil (Denight et al., 2008). Beds of landscape roses not frequently inspected for RRD symptomatic plants may serve as reservoirs for mites and virus.

RRD was first documented in Manitoba, Canada in 1940 (Conners, 1941). Shortly after, there were similar reports from Wyoming (in 1941) and California (in 1942) (Thomas and Scott, 1953). RRD has since spread to the south and east of the United States, and it is currently documented from 33 states, including: Alabama, Arkansas, California, Colorado, Connecticut, Delaware, Georgia, Illinois, Indiana, Iowa, Kansas, Kentucky, Louisiana, Maryland, Massachusetts, Michigan, Mississippi, Missouri, Nebraska, New Jersey, New York, North Carolina, Ohio, Oklahoma, Pennsylvania, South Carolina, Tennessee, Texas, Utah, Virginia, West Virginia, Wisconsin, and Wyoming (Amrine, 2002; Bauchan et al., 2019; Denight et al., 2008; Dobhal et al., 2016; Shires and Ong, 2018). Despite the wide incidence of RRD, the boundaries of the distribution are unknown, notably in the southeastern United States. With reports of RRD in the northern parts of Alabama, Georgia, and Mississippi (Shires and Ong, 2018) the southward extent of disease incidence in those states was unknown. There have been anecdotal reports of RRD infections as far south as Interstate I-20, a highway extending from Augusta through Atlanta, GA; Birmingham, AL; and Jackson, MS; but the absence of reports south (excepting reports from Florida discussed in the following) was intriguing

Distribution of the vector, $P$. fructiphilus, has also not been clearly determined, though previously reported in North America (Hoy, 2013) and as "widely distributed" on both wild and ornamental roses (Amrine, 2002). Because the natural spread of RRV relies on $P$. fructiphilus, the distribution of RRV could correlate with the distribution of these mites. However, it is possible that the mite may be present in the absence of the disease, including on rose species not prone to infection (e.g., R. palustris).
The mite has so far not been reported from the southern halves of the U.S. Gulf States (Alabama, Georgia, and Mississippi) (Hoy, 2013). In Nov. 2013, a case of RRV-infected 'Knock Out' roses was discovered in Florida and confirmed using reverse transcription polymerase chain reaction (RT-PCR); but no eriophyid mites were recovered from the infected roses (Babu et al., 2014). This discovery suggests that infected roses were shipped into Florida. Following quarantine and destruction of the symptomatic roses that tested positive for RRV, no spread of the disease has been observed (Babu et al., 2014). Subsequently, three more cases were confirmed in Florida from 2014 to 2018 in symptomatic plants shipped from other states, but no eriophyid mites were found on the plants.

A better understanding of the distribution of the mite could identify the risk of spread of $R R V$, given that the mite is the primary vector, along with transport of infected plants to areas where the disease is unknown to occur. Therefore, more information on the incidence of $P$. fructiphilus can help in predicting potential for locations where natural spread of RRV can occur. Nursery growers, public and private gardens, and those overseeing natural areas with invasive and native wild roses in the Deep South (the southeastern region of the United States including Alabama, Georgia, and Mississippi) could benefit from more information when assessing the potential for impact the disease may have. This study surveyed this region by sampling for both RRV-infection and populations of eriophyid mites on cultivated roses. The objectives of this study were to determine if $P$. fructiphilus and RRD were present in this region in managed areas; if certain factors such as wind barriers, sun exposure levels, or plant size were associated with the presence of eriophyid mites in these sites; and if plant hardiness zones or latitude could be used to predict the prevalence of the $P$. fructiphilus or RRD in the region.

\section{Materials and Methods}

Collection of samples. Samples were collected from June through November in 2017 from public and commercial cultivated rose landscaping plots in multiple cities within Alabama, Georgia, and Mississippi, with preference given to cities with populations greater than 1000 due to the likelihood of finding roses. There were 72 samples collected in Alabama, 83 in Georgia, and 49 in Mississippi (Fig. 1). At each sample location, information was recorded, including factors such as GPS coordinates, plant hardiness zone (USDA-ARS, 2012), sunlight exposure, 
presence of barriers (a physical obstruction to guard from wind), RRD symptoms, rose variety, plant size, as well as the number roses surrounding sampled plants. At every location, a sample of rose tissue was collected for future testing to determine if eriophyid mites were present: a $10-\mathrm{cm}$ terminal section-including stem and leaves-was placed in a $50-\mathrm{mL}$ tube with a screw cap containing $70 \%$ ethanol to preserve any collected eriophyid mites. Samples were placed in a cooler and stored at $5{ }^{\circ} \mathrm{C}$ until processed. At sites where roses exhibited typical RRD symptoms, additional terminal samples were collected $(\mathrm{n}=39)$ and placed in a cooler to determine if RRV was present. Symptoms suggestive of RRD included excessive thorniness, witch's-broom rosettes, an abundance of lateral shoots, shoots with abnormally persistent red coloration, mottled or deformed leaves and flowers, and lateral shoots with a wider girth than the parent cane (Amrine, 1996a; Di Bello et al., 2015; Hoy, 2013; Laney et al., 2011). Upon return to the laboratory, RRD samples were stored at $-20{ }^{\circ} \mathrm{C}$ until processed.

Mite extraction. Each rose sample collected for eriophyid mite detection $(\mathrm{n}=204)$ had the ethanol decanted and the tissue cut into $\approx 1-\mathrm{cm}$ pieces. Mites were extracted using a modified version of the Monfreda et al. (2007) procedure. The tissue was placed in an 80-mesh sieve with 270-mesh and 500mesh sieves placed below in a series; mesh openings were 180,53 , and $25 \mu \mathrm{m}$, respectively (Hogentogler, Columbia, MD). Ethanol was poured through the ascending sieve series. The tissue was rinsed with $\approx 2,000 \mathrm{~mL}$ of $70 \%$ ethanol. The 500-mesh screen was rinsed with $70 \%$ ethanol into a petri dish and examined under a stereomicroscope for the presence of eriophyid mites. Mites were isolated using a glass pipette and kept in a 1.5-mL Eppendorf tube with $70 \%$ ethanol. Isolated mites were stored at $5{ }^{\circ} \mathrm{C}$ until mounted on a microscope slide for identification.

Mounting mites. Mites were mounted in a modified Berlese mounting medium according to the procedure described by Amrine and Manson (1996). Mites were transferred from the tubes of ethanol using a glass pipette. Excess ethanol was absorbed by small pieces of filter paper. A minuten pin probe was used to transfer mites into a small drop of mounting medium. One slide was made per sampling location with mites recovered from the ethanol, with a maximum of 25 mites per slide. Using the minuten pin probe, the mites were oriented dorsally and ventrally for identification. This orientation allows for both the ventral coverflap and dorsal prodorsal shield to be viewed, both distinguishing morphological characteristics of eriophyid mites. A 12-mm coverslip was added, and the slide was cleared on a hot plate for $3 \mathrm{~h}$ at $50^{\circ} \mathrm{C}$. The slides were labeled and placed in an oven at $40{ }^{\circ} \mathrm{C}$ for 3-4 weeks to continue clearing and curing the medium. The slides were then sealed with clear nail polish and stored at room temperature.

Mite identification. Slides were viewed under a variety of microscopes, including an
Olympus BX-53 phase contrast microscope equipped with a 17-megapixel DP73 camera (Olympus, Tokyo, Japan) and an Olympus BX-63 differential interface contrast microscope equipped with a 14-megapixel Qcamera (Olympus). Ornamentation of the ventral genital coverflaps and prodorsal shields were the morphological characteristics used to identify the mite species. Additionally, several mites samples were viewed directly with a tabletop scanning electron microscope at the USDA-ARS in Beltsville, MD. Mites from the alcohol samples were placed on 25-mm SEM specimen stubs (Ted Pella, Redding, PA) with ultra-smooth, round (25 $\mathrm{mm}$ diameter) carbon adhesive tabs (Electron Microscopy Sciences, Inc., Hatfield, PA) affixed to the surface of the stub. The mites were simply removed from alcohol, briefly air-dried, and then mounted on the SEM stubs. Images of the mites were obtained using a Hitachi TM $3030+$ Table Top Scanning Electron Microscope (Hitachi High Technologies America, Inc., Dallas, TX) with a Deben TM-3000 Coolstage (Deben UK Ltd., Suffolk, U.K.) set at $-25{ }^{\circ} \mathrm{C}$. Images were viewed using the secondary electron detector set at charge reduced mode (variable pressure mode) with 15 $\mathrm{kV}$ accelerating voltage, a working distance of $8-12 \mathrm{~mm}$, and a magnification between $1000 \mathrm{x}$ and 2500x.

RNA purification. Total RNA, including the RRV RNA, was extracted from rose samples exhibiting RRD symptoms $(n=39)$ using the modified direct antigen capture method (Shires et al., 2018). Using a mesh ELISA bag (Agdia, Elkhart, IN), a pestle, 7 $\mathrm{mL}$ 1\% PBST (phosphate-buffered saline with Tween 20), and $2 \mathrm{~g}$ of leaves from each sample, cell contents were released from the sample. One $\mathrm{mL}$ of the sap and buffer solution was transferred to an Eppendorf tube and incubated in the refrigerator at $5{ }^{\circ} \mathrm{C}$ for $2 \mathrm{~min}$. The contents of the Eppendorf tubes were then poured out and discarded, and the tubes were rinsed six times with $1 \mathrm{~mL}$ of PBST, making certain no liquid was left in the tube after the last rinse. Tubes were placed on a $95^{\circ} \mathrm{C}$ heating block for $1 \mathrm{~min}$ and then were transferred back to $-20^{\circ} \mathrm{C}$ for about $5 \mathrm{~min}$. The RNA elution master mix was prepared by combining $2 \mu \mathrm{L}$ of RNasin (Promega, Madison, WI) with $30 \mu \mathrm{L}$ of sterile water. Then, $32 \mu \mathrm{L}$ of master mix was added to each sample to elute RNA from the Eppendorf tube surfaces. Samples were vortexed, centrifuged at $2680 \mathrm{~g}$ for $10 \mathrm{~s}$, and stored at $-20{ }^{\circ} \mathrm{C}$ until TaqMan RT-qPCR was performed.

TaqMan RT-qPCR. TaqMan-quantitative reverse transcription polymerase chain reaction (RT-qPCR) assays were performed using a Rose rosette virus forward primer (RRV2F), a reverse primer (RRV2R), and a TaqMan RRV2 Probe (Dobhal et al., 2016), using a Applied Biosystems QuantStudio 6 Flex Fast Real-time PCR System (ThermoFisher, Carlsbad, CA). The reaction mix consisted of $10.1 \mu \mathrm{L}$ RNase free water; 5 $\mu L$ Fast Virus 1 Step Master Mix (containing polymerase, enzyme, dNTPs, recombinant ribonuclease inhibitor, dye, and buffer) (Thermo-Fisher); $2 \mu \mathrm{L}(10 \mu \mathrm{M})$ Primer mix F/R RRV; $0.5 \mu \mathrm{L}(10 \mu \mathrm{M})$ TaqMan RRV Probe; $0.4 \mu \mathrm{L}$ Rox Reference Dye (50X) (Thermo-Fisher); and $2 \mu \mathrm{L}$ of RNA template for a final reaction volume of $20 \mu \mathrm{L}$. The controls included two positives and three negatives, of which one was RNase-free water. The positive RRV RNA controls came from roses naturally infected with RRV from Durant, OK. One positive control was extracted and stored at $-20{ }^{\circ} \mathrm{C}$ for 1 month, and another was extracted at the time of this experiment. The negative controls were two asymptomatic roses from the University of Tennessee Plateau AgResearch and Education Center in Crossville, TN. The TaqMan RT-qPCR amplification protocol consisted of an initial stage $50^{\circ} \mathrm{C}$ for $5 \mathrm{~min}$, a holding stage of $95^{\circ} \mathrm{C}$ for $20 \mathrm{~s}$, followed by 40 cycles of $95{ }^{\circ} \mathrm{C}$ for $15 \mathrm{~s}$ and $60{ }^{\circ} \mathrm{C}$ for 1 min, according to the manufacturer's suggestions. Data acquisition and analysis were preformed using the Applied Biosystem's QuantStudio 6 software.

Statistical analysis. Three separate generalized linear mixed models with binary distributions and logit link were developed to test factors associated with the probabilities of observing symptoms, finding P. fructiphilus, and $E$. eremus mites within sampled plants. Models were developed using the GLIMMIX procedure in SAS 9.4 (Littell et al., 2006). Factors included in model building were latitude, plant hardiness zone, cultivar, plant size, light availability, and wind barrier locations. Plants that were symptomatic were further analyzed for RRV by TaqMan RT-qPCR. Multilevel logistic regression was performed to test factors associated with the probability of detecting RRV from tested plants.

Manual forward model selection was used to determine the best fitting explanatory variables for all analyses. Odds ratio estimates, 95\% confidence limits, and model-adjusted probabilities were obtained. Statistical significance was determined at $\alpha=0.05$.

\section{Results}

Eriophyid mites were recovered from about half of the sample locations (Fig. 2). Of the 106 samples that contained eriophyid mites, 91 samples of mites could be morphologically identified. Three different species of eriophyid mites were found in different sampling locations in at least two states, including P. fructiphilus (Figs. 3 and 4), E. eremus, and an unidentified mite denoted as 'Unknown A' based on descriptions by Amrine (1996b) and Druciarek and Lewandowski (2016).

Eriophyid mites were found on samples taken from throughout Alabama, Georgia, and Mississippi. P. fructiphilus, formerly not thought to be present in the southern half of the Deep South, was found in 60 locations and as far south as the cities of Wiggins, 


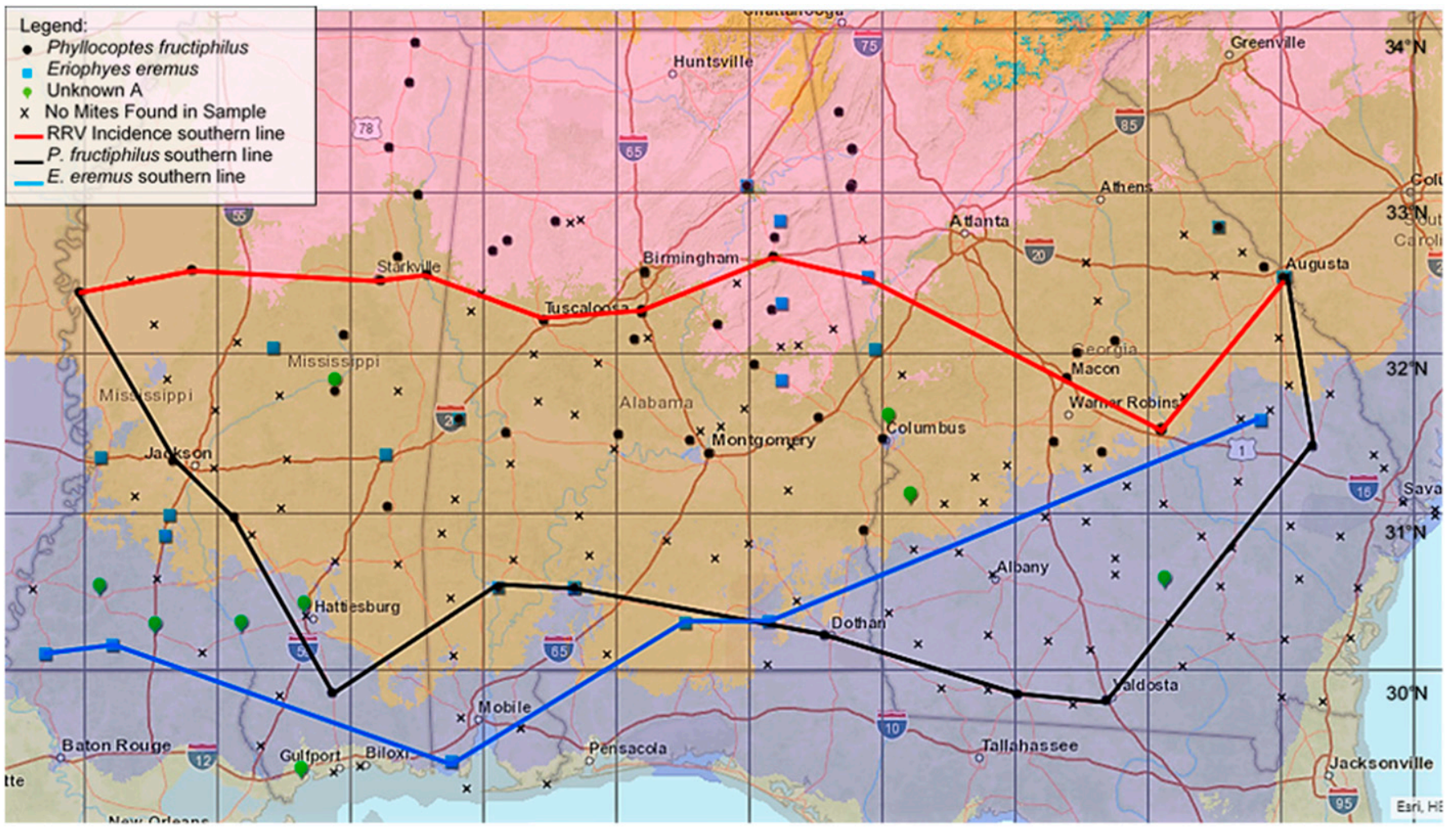

Fig. 1. Map of the southern incidence line of Rose rosette virus (RRV) and eriophyid mites in Alabama, Georgia, and Mississippi in 2017. Plant hardiness Zone 7b is in pink, Zone $8 \mathrm{a}$ is brown, Zone $8 \mathrm{~b}$ is blue, and Zone $9 \mathrm{a}$ is in gray. Note that there are five locations in which two mite species were found on the same rose sample.

MS; Dothan, AL; and Valdosta, GA, in many cases not in association with RRV symptoms. E. eremus was found in 24 locations, across all three states. "Unknown A" was found in nine locations in Georgia and Mississippi (Fig. 1). There were five locations where two mite species were found on the same sample. Four of these locations had both $P$. fructiphilus and E. eremus, while one location had P. fructiphilus and "Unknown A."

When roses exhibited RRD symptoms, a sample of rose plant tissue was taken for RRV detection $(\mathrm{n}=39)$. Of the total 39 samples that were tested for RRV, 29 tested positive by Taqman RT-qPCR, or $74.4 \%$ (Table 1). The positive samples were mapped to show the southern edge of the distribution of RRV in the southeastern United States (Fig. 1).

The latitude of the sampled plants was significantly correlated with the probability of detecting RRV $(P=0.01)$ in plants with symptoms; however, plant hardiness zone was not $(P=0.83)$. For each degree increase in latitude, the odds for RRV-positive results increased by 8.2 times over the chance of detection in samples from one degree less in latitude (OR: 8.2, 95\% CI: 1.58-42.6).

The number of eriophyid mites in a sample $(P=0.001)$ and the plant hardiness zone $(P=0.006)$ were both significantly correlated with the probability of observing symptoms in sampled plants. As the number of mites increased by 10 , the symptoms of RRD were 1.25 times more likely to be observed (OR: 1.25, 95\% CI: 1.1-1.4) (Fig. 2).
Table 1. Characteristics of rose rosette samples from Alabama, Georgia, and Mississippi.

\begin{tabular}{|c|c|c|c|c|}
\hline Rose cultivar & Location & Observable symptoms & CT value & RRV presence \\
\hline Knock Out & Anniston, AL & Yes & 27.593 & Positive \\
\hline Unknown & Birmingham, $\mathrm{AL}$ & Yes & 25.751 & Positive \\
\hline Knock Out & Gadsden, AL & Yes & 24.846 & Positive \\
\hline Unknown & Livingston, $\mathrm{AL}$ & Possible & No CT & Negative \\
\hline Knock Out & Northport, AL & Yes & 24.875 & Positive \\
\hline Knock Out & Oxford, AL & Yes & 23.240 & Positive \\
\hline Unknown & Pelham, AL & Possible & 28.646 & Positive \\
\hline Knock Out & Townley, AL & Yes & 20.213 & Positive \\
\hline Drift & Augusta, GA & Possible & 27.794 & Positive \\
\hline Drift & Augusta, GA & Yes & 25.646 & Positive \\
\hline Knock Out & Augusta, GA & Yes & 26.266 & Positive \\
\hline Knock Out & Bremen, GA & Yes & 31.197 & Positive \\
\hline Knock Out & Brunswick, GA & Possible & No CT & Negative \\
\hline Knock Out & Cedartown, GA & Yes & 27.431 & Positive \\
\hline Knock Out & Cedartown, GA & Yes & 27.099 & Positive \\
\hline Knock Out & Columbus, GA & Possible & No CT & Negative \\
\hline Knock Out & Dublin, GA & Yes & 23.786 & Positive \\
\hline Knock Out & Dublin, GA & Yes & 24.509 & Positive \\
\hline Knock Out & Evans, GA & Possible & No CT & Negative \\
\hline Knock Out & LaGrange, GA & Possible & No CT & Negative \\
\hline Knock Out & Lincolnton, GA & Yes & 23.948 & Positive \\
\hline Knock Out & Macon, GA & Possible & No CT & Negative \\
\hline Knock Out & Madison, GA & Yes & 26.701 & Positive \\
\hline Knock Out & Madison, GA & Yes & 29.535 & Positive \\
\hline Knock Out & Pine Mountain, GA & Possible & No CT & Negative \\
\hline Knock Out & Rome, GA & Yes & 27.307 & Positive \\
\hline Knock Out & Rome, GA & Yes & 25.944 & Positive \\
\hline Knock Out & Roopville, GA & Yes & 24.066 & Positive \\
\hline Knock Out & Summerville, GA & Possible & No CT & Negative \\
\hline Knock Out & Tybee, GA & Possible & No CT & Negative \\
\hline Knock Out & Boonville, MS & Yes & 23.982 & Positive \\
\hline Knock Out & Columbus, MS & Yes & 25.044 & Positive \\
\hline Knock Out & Corinth, MS & Yes & 23.421 & Positive \\
\hline Knock Out & Greenville, MS & Yes & 23.063 & Positive \\
\hline Knock Out & Greenwood, MS & Yes & 23.701 & Positive \\
\hline Knock Out & Indianola, MS & Possible & No CT & Negative \\
\hline Knock Out & Starkville, MS & Yes & 30.210 & Positive \\
\hline Unknown & Tupelo, MS & Yes & 23.910 & Positive \\
\hline Knock Out & West Point, MS & Yes & 23.949 & Positive \\
\hline
\end{tabular}




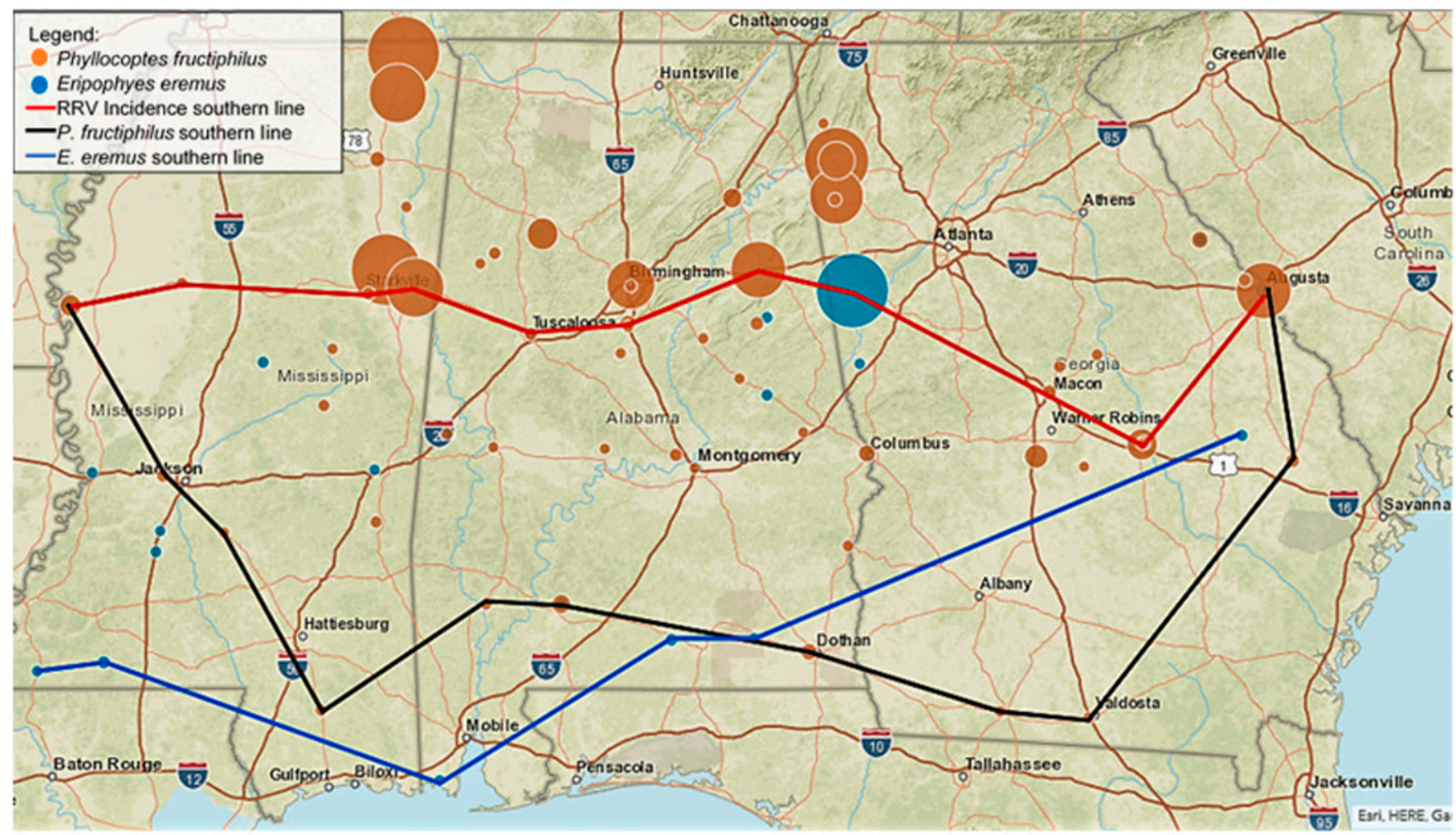

Fig. 2. Map of the southern incidence line of Rose rosette virus (RRV), southern distribution of Phyllocoptes fructiphilus and Eriophyes eremus, and the population densities of eriophyid mites found on rose samples in Alabama, Georgia, and Mississippi in 2017. The larger the circle, the more mites found in the sample.

USDA plant hardiness Zone 9a (USDAARS, 2012) had few observations, therefore Zones $8 \mathrm{~b}$ and $9 \mathrm{a}$ were combined for analysis (referred to as "Zone $8 \mathrm{~b}$ "). Of the samples collected, $13.2 \%$ were in Zone 7b, 49.5\% were in Zone $8 \mathrm{a}$, and $36.8 \%$ were in Zone 8b. RRD symptoms were 18.4 times more likely to be found in Zone $7 \mathrm{~b}$ compared with Zone $8 \mathrm{~b}(\mathrm{OR}=18.4$; 95\% CI: 3.2-107.7) and 8 times more likely in Zone 8 a compared with Zone $8 \mathrm{~b}(\mathrm{OR}=7.96$; 95\% CI: 1.6-38.8).

Plant hardiness zones $(P=0.006)$ and presence of RRD symptoms $(P=0.0002)$ were correlated with the probability of finding $P$. fructiphilus. While we saw no difference between Zones $7 \mathrm{~b}$ and $8 \mathrm{a}$ in the odds of finding $P$. fructiphilus $(P=0.69), P$. fructiphilus was significantly more likely to be found in Zone $7 \mathrm{~b}$ compared with Zone $8 \mathrm{~b}$ $(\mathrm{OR}=3.591 ; 95 \%$ CI: 1.01-12.81). Likewise, $P$. fructiphilus was significantly more likely to be found in Zone $8 \mathrm{a}$ vs. Zone $8 \mathrm{~b}$ $(\mathrm{OR}=4.43 ; 95 \% \mathrm{CI}: 1.78-11.02)$. Where RRD symptoms were observed, the presence of $P$. fructiphilus was significantly more likely $(\mathrm{OR}=10.64$; 95\% CI: $3.4-33.3) \mathrm{com}-$ pared with plants where no RRD symptoms were observed.

Plot factors were also analyzed for the presence of $E$. eremus. Both cultivar ( $P=$ $0.02)$ and light conditions $(P=0.05)$ were correlated with the presence of $E$. eremus. $E$. eremus was significantly more likely to be found on 'Drift' vs. 'Knock Out' roses (OR =
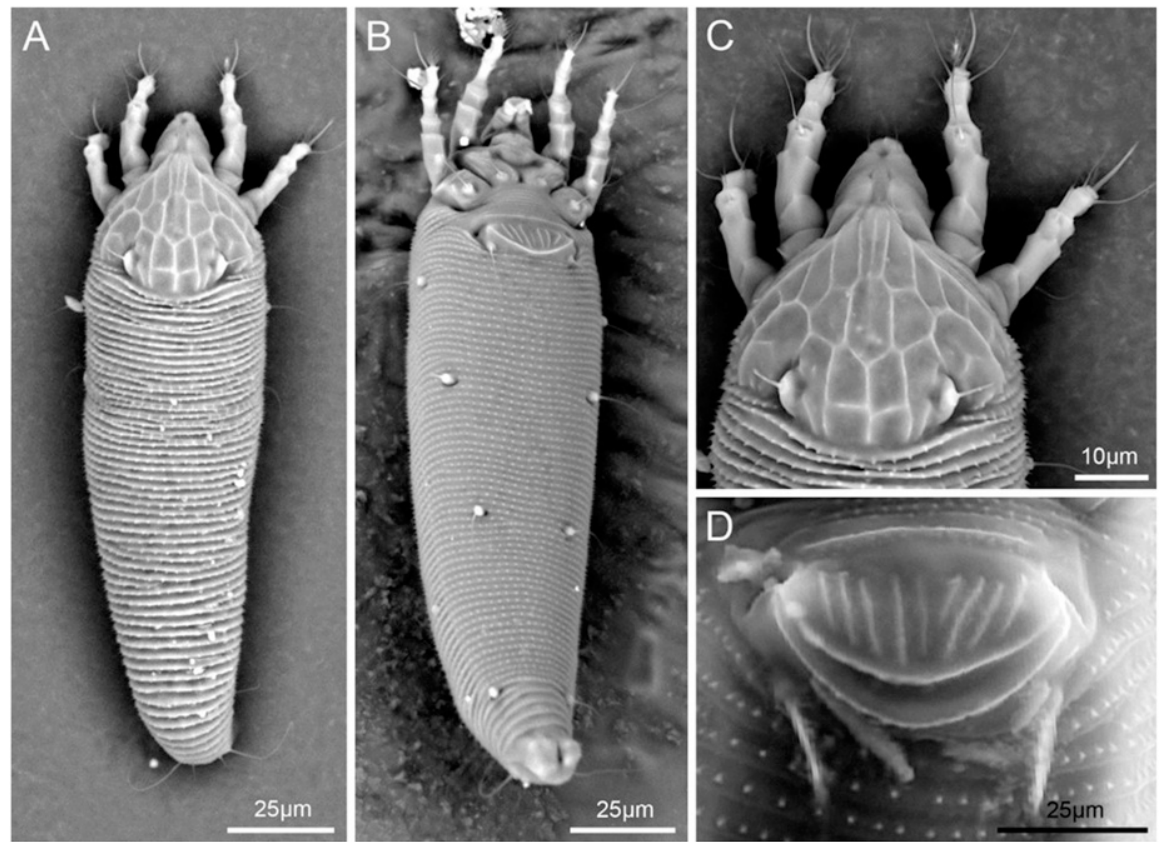

Fig. 3. Table Top-SEM images of Phyllocoptes fructiphilus adult, vector of Rose rosette virus: (A) dorsal view, (B) ventral view, (C) prodorsal shield, and (D) ventral cover flap.

5.45: $95 \%$ CI: 1.7-17.5). There appeared to be an elevated correlation of finding $E$. eremus in samples from full sun conditions compared with partial sun $(\mathrm{OR}=0.383 ; 95 \%$ CI: 0.15-1.0).

\section{Discussion}

There are increasing reports of both RRV from around the United States and the eriophyid mites that are found on roses, but there 


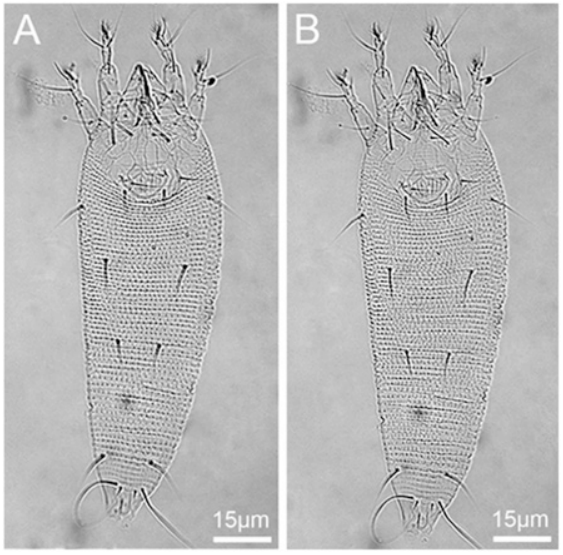

Fig. 4. Differential Interference Contrast Microscopy images of Phyllocoptes fructiphilus, vector of Rose rosette virus: (A) dorsal view and (B) ventral view.

are no prior studies focusing on these two factors to better understand their distribution and association, especially in the southeastern United States, as done in this study.

Previously, a geographical limit for incidence for RRV was unknown. As shown in Fig. 1, it appears the southeastern distribution and southern limit has now been defined for symptomatic RRV infections. The sampling techniques used in this study allowed a snapshot of RRV incidences occurring in the same year to be recorded instead of just integrating and cataloging all historic cases of RRD. In this way, our line of incidence might be considered as the disease's current front. This line of reference will be useful in future studies to track and compare the spread of RRD. It was decided to use visible RRD symptoms as a prerequisite for sample collection due to the cost of testing each sample for RRV RNA with TaqMan RT-qPCR. However, because of the collection of samples in this study, asymptomatic infections of RRV have been discovered. Although we are confident in our current geographical southern boundary for incidence of symptomatic $\mathrm{RRV}$ infection, it is possible the virus may reside in asymptomatic roses further south of the line.

A similar survey in 2017 in northern and central Florida (Martini, data not shown) found RRD only on a few plants recently introduced into the state, but the disease did not become established. Following the same sampling method as in our current research, no eriophyid mite vectors were found at the Florida sites, or in the Florida landscape. However, the lack of vector presence and the failure of the disease to become established does not absolve rose growers located below the RRV and $P$. fructiphilus lines of vigilance, because both disease and vector can be transported wherever roses are shipped.

In cooler zones (Zones $7 \mathrm{~b}$ and $8 \mathrm{a}$ in this study), there were much higher chances of observing symptoms of RRD in roses. Although, plant hardiness zones were not asso- ciated with the positive RRV detections. This could be because not all samples were tested for RRV presence, but only those samples from symptomatic plants. Symptomatic roses growing at higher latitudes had significantly higher chances of testing positive for RRV compared with symptomatic plants at lower latitudes. Although we suggest that any rose grower in this region remain vigilant for symptoms of RRD, our results indicate that latitude could be used as a tool to predict if RRD might be present in roses or not.

Factor such as wind barriers, sun exposure levels, and plant size were taken at each sampling locations. It is unknown if any of these factors affect the presence of eriophyid mites or RRD in roses. Eriophyid mites spread naturally by floating on wind currents. We wanted to specifically look at the size of the plant and if there were any wind barriers nearby such as walls, trees, or other large plants that could prevent mites from accessing the plant by wind. However, plant size and wind barriers were not found to be significantly associated with any outcome of interest tested. Likewise, sun exposure (full sun, part sun, and shade) conditions were also examined and had no significate association with $P$. fructiphilus or the presence of RRD. E. eremus was found to be significantly associated with full sun environments and 'Drift' roses, factors that may influence future research with this species.

The presence of eriophyid mites in most samples, both symptomatic and asymptomatic for RRV, was not surprising. However, finding $P$. fructiphilus in most of the samples was unexpected in the southern halves of the states where RRD was not observed. $E$. eremus was described in 2016 (Druciarek and Lewandowski, 2016) and has only recently been found in five states, including Georgia (Otero-Colina et al., 2018). This study also found $E$. eremus in Alabama and Mississippi, resulting in a first report for this mite in those states. Most interestingly, $E$. eremus was found at a high population level ( $258 \mathrm{mites} / \mathrm{g}$ of tissue) on a rose plant that was severely symptomatic for RRD and TaqMan RT-qPCR positive. No other mite species were present on this sample, not even $P$. fructiphilus. There has not been any damage observed to host plants due to E. eremus feeding (Otero-Colina et al., 2018) that may imitate certain RRD symptoms. Because this mite was newly found in North America, the only continent in which RRV is known to naturally occur, further examination is required to discover whether E. eremus can play a role in RRV transmission. Better characterization of the relationship of rose eriophyid mites with other species occupying the same rose plant, and on both wild and cultivated species, is also critically needed information. Five of the 204 samples in this study had two species of eriophyid mites. Both $E$. eremus and $P$. fructiphilus are refuge-seeking mites and may compete for the same feeding locations and niches for protection from predators and the environment. We are also not certain whether there is a strong host or cultivar preference, particularly in E. eremus.

The unidentified mite, "Unknown A," was found in nine different samples in both Georgia and Mississippi. One sample from a location in Mississippi contained both "Unknown A" and P. fructiphilus. We were unable to place "Unknown A" to genus using a key by Lindquist and Amrine (1996). Additional live specimens are needed to collect morphological, behavioral, and genetic information before this mite can be identified.

Figure 1 shows the distribution of the three mites found in this study. Our work shows the distribution of $P$. fructiphilus much farther south than previously thought (Hoy, 2013) throughout all three states, albeit in small populations. In fact, the largest populations of eriophyid mites, including $P$. fructiphilus were found either at (or north) of the RRV line of incidence, with no populations greater than 10 mites per gram south of the RRV line (Fig. 2). It is also known that $P$. fructiphilus tends to be more abundant on roses symptomatic with RRD than asymptomatic roses (Amrine, 1996a; Epstein and Hill, 1999; Jesse et al., 2006). Future research will need to examine what factors might limit the mites' presence south of this RRV incidence line, such as humidity, temperature, wind patterns, plant physiology, lack of RRD symptomatic roses, pathogenic fungi, or predatory mites. In this study, mite identification was prioritized over testing them for presence of RRV; however in future studies, this could be an interesting factor, especially in mite species other than $P$. fructiphilus, to better understand the relationship between virus and host, as well as learn whether there may be other vectors of RRV.

This is the first comprehensive examination of rose eriophyid mites in the Deep South. This data will be instrumental in forming future research directions regarding eriophyid mites and RRD. Future surveys can be used in combination with this study to assess the spread of this disease and its vector(s).

\section{Literature Cited}

Allington, W.B., R. Staples, and G. Viehmeyer 1968. Transmission of Rose Rosette Virus by the eriophid mite Phyllocoptes fructiphilus. J. Econ. Entomol. 61:1137-1140.

Amrine, J., Jr. and D. Manson. 1996. Preparation, mounting and descriptive study of eriophyoid mites, p. 383-396. In: E. Lindquist, M. Sabelis, and J. Bruin (eds.). Eriophyoid mites-Their biology, natural enemies and control, vol. 6 . Elsevier Science Publishing, Amsterdam, The Netherlands.

Amrine, J.W. 1996a. Phyllocoptes fructiphilus and biological control of multiflora rose, p. 741749. In: E. Lindquist, M. Sabelis, and J. Bruin (eds.). Eriophyoid mites-Their biology, natural enemies and control, vol. 6. Elsevier Science Publishing, Amsterdam, The Netherlands.

Amrine, J.W. 1996b. Keys to the world genera of the Eriophyoidea. Indira Pub. House, West Bloomfield, MI

Amrine, J.W., Jr. 2002. Multiflora rose, p. 265 292. In: R. Van Driesche, S. Lyon, B. Blossey, 
M. Hoddle, and R. Reardon (eds.). Biological control of invasive plants in the eastern United States, vol. FHTET-2002-04. USDA Forest Service Publication.

Amrine, J.W., Jr., D.F. Hindal, T.A. Stasny, R.L. Williams, and C.C. Coffman. 1988. Transmission of the rose rosette disease agent to Rosa multiflora by Phyllocoptes fructiphilus (Acari: Eriophyidae). Entomol. News 99:239-252.

Babu, B., H. Dankers, E. Newberry, C. Baker, T. Schubert, G. Knox, and M. Paret. 2014. First report of rose rosette virus associated with rose rosette disease infecting knockout roses in Florida. Plant Dis. 98:1449.

Baker, E.W., T. Kono, J.W. Amrine, M. DelfinadoBaker, and T.A. Stasny. 1996. Eriophyoid mites of the United States. Indira Pub House, West Bloomfield, MI.

Bauchan, G., G. Otero-Colina, J. Hammond, R. Jordan, and R. Ochoa. 2019. Rose rosette disease: It all started with a small mite. Acta Hort. 1232:227-232.

Conners, I.L. 1941. Twentieth annual report of the Canadian Plant Disease Survey 1940, p. 97-98.

Denight, M.L., P.J. Guertin, D.L. Gebhart, and L. Nelson. 2008. Invasive species biology, control, and research. Part 2, Multiflora rose (Rosa multiflora). In: R. Engineer (ed.). Environmental Laboratory, U.S. Army Engineer Research and Development Center, Vicksburg, MS.

Di Bello, P.L., T. Ho, and I.E. Tzanetakis. 2015. The evolution of emaraviruses is becoming more complex: Seven segments identified in the causal agent of rose rosette disease. Virus Res. 210:241-244.

Dobhal, S., J.D. Olson, M. Arif, J.A. Garcia Suarez, and F.M. Ochoa-Corona. 2016. A simplified strategy for sensitive detection of Rose Rosette Virus compatible with three RT-PCR chemistries. J. Virol. Methods 232:47-56.
Druciarek, T. and M. Lewandowski. 2016. A new species of eriophyoid mite (Acari: Eriophyoidea) on Rosa sp. from Israel. Zootaxa 4066:323-330.

Epstein, A.H. and J.H. Hill. 1999. Status of rose rosette disease as a biological control for multiflora rose. Plant Dis. 83:92-101.

Galvao, A., J. Melo, V. Monteiro, D. Lima, G. Moraes, and M. Gondim, Jr. 2012. Dispersal strategies of Aceria guerreronis (Acari: Eriophyidae), a coconut pest. Exp. Appl. Acarol. 57:1-13.

Gergerich, R. and K. Kim. 1983. A description of the causal agent of rose rosette disease. Arkansas Farm Research 32.

Hoy, M. 2013. Common name: Eriophyid mite vector of rose rosette disease (RRD) scientific name: Phyllocoptes fructiphilus Keifer (Arachnida: Acari: Eriophyidae), p. EENY-558. In: J.L. Gillett-Kaufman (ed.). Featured creature. University of Florida, Gainsville, FL.

Jesse, L.C., K. Moloney, and J. Obrycki. 2006. Abundance of arthropods on the branch tips of the invasive plant, Rosa multiflora (Rosaceae). Weed Biol. Manage. 6:204-211.

Keifer, H.H. 1939a. Eriophyid studies VII. Bull Cali. Dept. Agr. 28:487.

Keifer, H.H. 1939b. Eriophyid studies IV. Bull. Cali. Dept. Agr. 28:234.

Keifer, H.H. 1940. Eriophyid studies VIII. Bull. Cali. Dept. Agr. 29:21-46.

Keifer, H.H. 1972. Eriophyid studies C-7. USDAARS 11:1-24.

Laney, A.G., I.E. Tzanetakis, K.E. Keller, and R.R. Martin. 2011. A discovery 70 years in the making: Characterization of the Rose Rosette Virus. J. Gen. Virol. 92:1727-1732.

Lindquist, E.E. and J.W. Amrine. 1996. Systematics, diagnoses for major taxa, and keys to families and genera with species on plants of economic importance, p. 33-87. In: E. Lind- quist, M. Sabelis, and J. Bruin (eds.). Eriophyoid mites - Their biology, natural enemies and control, vol. 6. Elsevier Science Publishing, Amsterdam, The Netherlands.

Lindquist, E. and G. Oldfield. 1996. Evolution of eriophyoid mites in relation to their host plants, p. 277-300. In: E. Lindquist, M. Sabelis, and J. Bruin (eds.). Eriophyoid mites - Their biology, natural enemies and control, vol. 6. Elsevier Science Publishing, Amsterdam, The Netherlands.

Littell, R.C., G.A. Milliken, W.W. Stroup, R.D. Wolfinger, and O. Schabenberger. 2006. SAS for mixed models. 2nd ed. SAS Institute, Cary, NC.

Monfreda, R., G. Nuzzaci, and E. De Lillo. 2007. Detection, extraction, and collection of Eriophyoid mites. Zootaxa 1662:35-43.

Otero-Colina, G., R. Ochoa, J.W. Amrine, J. Hammond, R. Jordan, and G.R. Bauchan. 2018. Eriophyoid mite found on healthy and rose rosette diseased roses in the United States. J. Environ. Hort. 36(4):146-153.

Shires, M. and K. Ong. 2018. Rose rosette distribution map. In: J. Laforest (ed.). 25 Mar. 2019. $<$ https://roserosette.org/>.

Shires, M., J. Ueckert, and K. Ong. 2018. Rose rosette virus: Effective and low-cost extraction method. HortScience 53:S407.

Styer, W.E. 1974. A new species of Phyllocoptes (Acarina, Eriophyidae) from rose. Entomol. News 85:202-204.

Thomas, E.A. and C.E. Scott. 1953. Rosette of rose. Phytopathology 43:218-219.

USDA-ARS. 2012. Agricultural Research Service, Plant hardiness zone map 2012. 30 Mar. 2020. $<$ https://planthardiness.ars.usda.gov/>.

Zhao, S. and J.W. Amrine, Jr. 1997. Investigation of snowborne mites (acari) and relevancy to dispersal. Intl. J. Acarol. 23:209-213. 